\title{
Monetary Policy, Housing Rents, and Inflation Dynamics
}

Dias, Daniel A. and João B. Duarte

Please cite paper as:

Dias, Daniel A. and João B. Duarte (2019). Monetary Policy,

Housing Rents and Inflation Dynamics. International Finance

Discussion Papers 1248.

https://doi.org/10.17016/IFDP.2019.1248

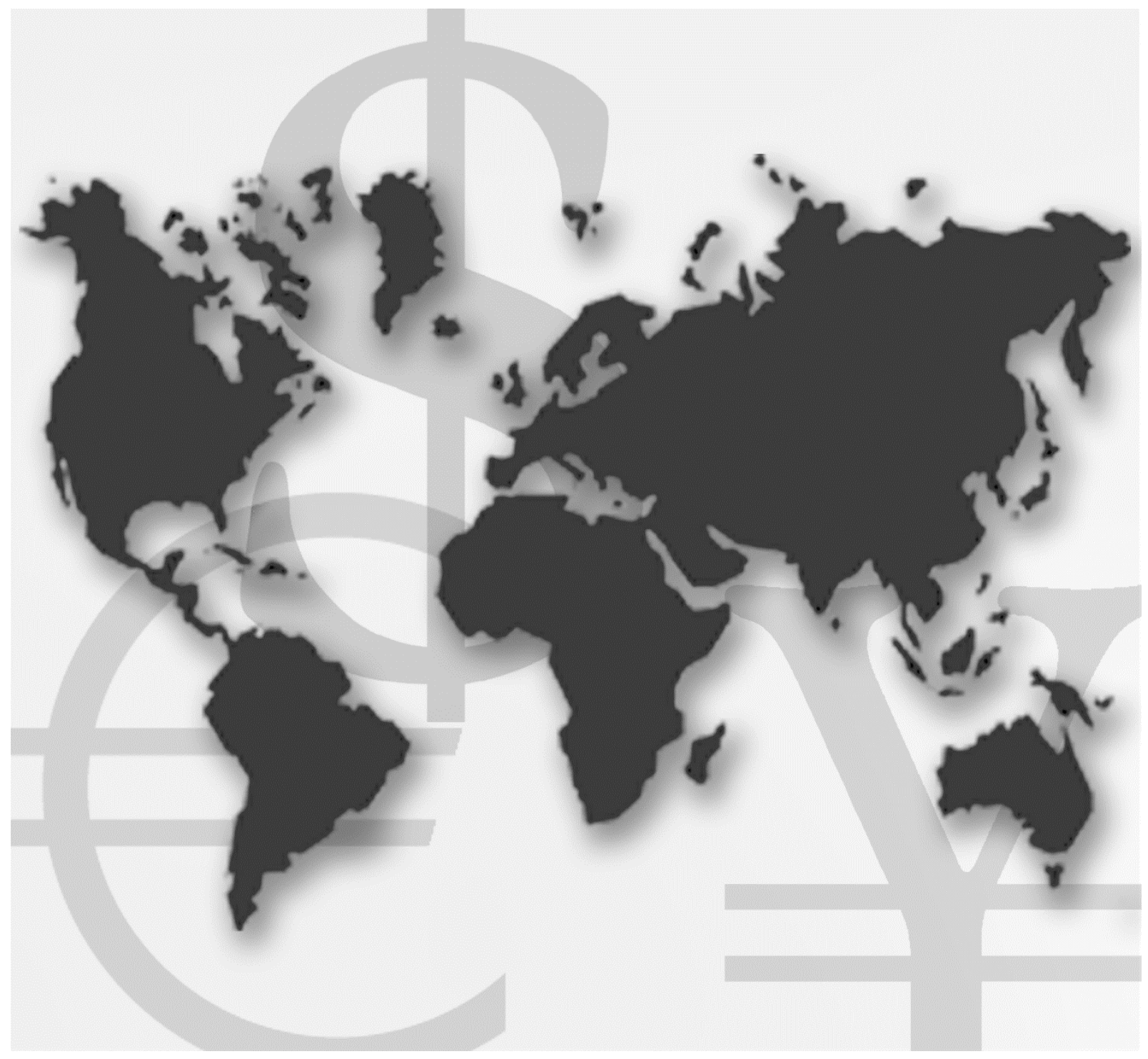

\section{International Finance Discussion Papers}

Board of Governors of the Federal Reserve System

Number 1248

May 2019 
Board of Governors of the Federal Reserve System

International Finance Discussion Papers

Number 1248

May 2019

\title{
Monetary Policy, Housing Rents, and Inflation Dynamics
}

\author{
Daniel A. Dias and João B. Duarte
}

NOTE: International Finance Discussion Papers are preliminary materials circulated to stimulate discussion and critical comment. References to International Finance Discussion Papers (other than an acknowledgment that the writer has had access to unpublished material) should be cleared with the author or authors. Recent IFDPs are available on the Web at www.federalreserve.gov/pubs/ifdp/. This paper can be downloaded without charge from the Social Science Research Network electronic library at www.ssrn.com. 


\title{
Monetary Policy, Housing Rents, and Inflation Dynamics*
}

\author{
Daniel A. Dias ${ }^{\dagger} \quad$ João B. Duarte ${ }^{\ddagger}$
}

May 2019

\begin{abstract}
In this paper we study the effect of monetary policy shocks on housing rents. Our main finding is that, in contrast to house prices, housing rents increase in response to contractionary monetary policy shocks. We also find that, after a contractionary monetary policy shock, rental vacancies and the homeownership rate decline. This combination of results suggests that monetary policy may affect housing tenure decisions (own versus rent). In addition, we show that, with the exception of the shelter component, all other main components of the consumer price index (CPI) either decline in response to a contractionary monetary policy shock or are not responsive. These findings motivated us to study the statistical properties of alternative measures of inflation that exclude the shelter component. We find that measures of inflation that exclude shelter have most of the statistical properties of the widely used measures of inflation, such as the CPI and the price index for personal consumption expenditures (PCE), but have higher standard deviations and react more to monetary policy shocks. Finally, we show that the response of housing rents accounts for a large proportion of the "price puzzle" found in the literature.
\end{abstract}

JEL classification codes: E31, E43, R21.

Keywords: Monetary policy; Housing rents; Inflation dynamics; "Price puzzle”; Housing tenure.

${ }^{*}$ The authors thank, without implicating, the editor Jonathan Wright, two anonymous referees, Alejandro Justiniano, Anne Villamil, Antonella Tutino, Dan Bernhardt, Harald Uhlig, Igor Ezio, Leonardo Melosi, Mark Wright, Rui Zhao, Stephen Parente, Woong Yong Park, Chris Sims, and various participants at the Chicago Fed seminar, the Federal Reserve Board seminar, the Bank of Portugal research seminar series, the Georgetown Center for Economic Research Biennial Conference, the "Interaction between Housing and the Economy" workshop, the 2015 Econometric Society World Congress, and the macro reading group at the University of Illinois at Urbana-Champaign (UIUC) for helpful suggestions and discussions. This research was supported by the Paul Boltz Fellowship and the UIUC campus research board with an Arnold O. Beckman Research Award. João B. Duarte gratefully acknowledges financial support from the ADEMU project and the Fundação para a Ciência e Tecnologia (FCT). This paper supersedes the paper "The Effect of Monetary Policy on Housing Tenure Choices as an Explanation for the Price Puzzle" and incorporates some of the empirical results presented in an earlier version of the paper "Housing and Monetary Policy in the Business Cycle: What do Housing Rents Have to Say?". The views in this paper are solely the responsibility of the authors and should not be interpreted as reflecting the views of the Board of Governors of the Federal Reserve System or of any other person associated with the Federal Reserve System. All errors are our own.

${ }^{\dagger}$ Board of Governors of the Federal Reserve System and CEMAPRE. Email: daniel.dias@frb.gov.

${ }^{\ddagger}$ Nova School of Business and Economics. Email: joao.duarte@novasbe.pt. 


\section{Introduction}

It is now a well-established result that the housing sector plays an important role in the transmission mechanism of monetary policy (Iacoviello (2005), Del Negro and Otrok (2007), Calza et al. (2013), and Luciani (2015) are examples of studies showing the effects of monetary policy on housing). Most of the literature on housing and monetary policy has primarily focused on house prices and residential investment, and, to the best of our knowledge, there are no studies on the effect of monetary policy on housing rents. In this paper we fill this gap in the literature and use a smallscale proxy structural vector autoregressive (SVAR) model to study the effect of monetary policy shocks on housing rents.

Our main finding is that, in contrast to house prices, housing rents increase after a contractionary monetary policy shock. We also find that, after a contractionary monetary policy shock, rental vacancies and the homeownership rate decline. This combination of results suggests that monetary policy may affect housing tenure decisions (own versus rent). In addition, we show that, with the exception of shelter, all other main components of the consumer price index (CPI) or the price index of personal consumption expenditure (PCE) either decline in response to contractionary monetary policy shocks or are not responsive. These findings motivated us to study the statistical properties of alternative measures of inflation that exclude the shelter component. Relative to the widely used measures of inflation, such as the CPI or PCE, these alternative measures of inflation have a slightly lower mean, a slightly higher variance, but similar autocorrelation patterns to those of existing measures of inflation. Importantly, we find that these alternative measures of inflation react more to monetary policy shocks. We also show that the response of housing rents accounts for a large proportion of the "price puzzle" found in the literature. Our findings contribute to the literature on housing and macroeconomics and to the literature on inflation dynamics.

Although housing was not completely absent from the macroeconomics literature before the global financial crisis, it was seen as a minor component of the economy which did not deserve special attention (Piazzesi and Schneider (2016)). However, since the great financial crisis, housing has gained much more attention in the macroeconomics literature, as it became clear that housing was much more important than previously recognized. A distinctive characteristic of housing is that it is not only an asset (the land and the dwelling) but also a consumption good (in the form of housing services). As a consumption good, housing services have the largest weight in the consumption bundle of the typical household, and, for most households, their house is their most important as- 
set. As such, shocks that affect the cost of housing consumption or the price of houses are likely to have first-order effects in the welfare of most households. We contribute to this literature by showing that monetary policy affects the housing market by simultaneously affecting house prices and house rents, but with opposite effects on such prices and rents.

Our finding about the effect of monetary policy on housing rents has important implications for inflation dynamics because, directly and indirectly, rents have a weight of about $30 \%$ in the CPI and about $15 \%$ in the PCE. Therefore, the response of consumer prices to monetary policy shocks combines the responses of housing and non-housing prices. We show that, relative to the CPI and the PCE, a measure of prices that excludes shelter prices has a larger response to monetary policy shocks than do the measures of prices that include all goods. In other words, we find that low responses of overall consumer prices to monetary policy shocks are the result of strong opposing movements in nominal housing rents and the nominal prices of all other goods in the economy. This result suggests that consumer prices in the United States may be more responsive to monetary policy shocks than currently thought (Gertler and Karadi (2015), Pivetta and Reis (2007)). A higher level of consumer price responsiveness has implications for the trade-off between price stability and economic growth. On the one hand, the monetary policy authority can control prices with smaller monetary shocks; on the other hand, if prices are more responsive to monetary policy shocks, the monetary authority will possibly have to accept higher inflation when it tries to close negative output gaps. (For a discussion about the tradeoff between price stability and economic growth, see Woodford (2000), Erceg et al. (2000), or Debortoli et al. (2017)).

Finally, we find that, for the approaches for identifying monetary policy shocks that still produce a "price puzzle" (Romer and Romer (2004), and Bernanke et al. (2005)), the measures of inflation that exclude shelter costs show a much reduced "price puzzle". Therefore, the response of housing rents to monetary policy shocks goes a long way in explaining this puzzle.

The rest of the paper is organized as follows: in section 2, we present the empirical methodology and describe the data used; in section 3, we present the results relating to the effects of monetary policy on housing rents; in section 4, we discuss the implications of housing prices for inflation dynamics; and in section 5, we conclude. 


\section{Methodology}

To study the effect of monetary policy on housing rents, we use a small-scale proxy SVAR model as in Gertler and Karadi (2015). We describe this approach in the next sub-section, and the data we use, the way we select the number of lags in the SVAR model, and how we conducted statistical inference in the following.

\subsection{Proxy SVAR}

Let $Y_{t}$ be an $n \times 1$ vector of observable time series variables. An SVAR with $p$ lags is given by:

$$
Y_{t}=A_{1} Y_{t-1}+A_{2} Y_{t-2}+\ldots+A_{p} Y_{t-p}+H \varepsilon_{t}
$$

where $I_{n}, A_{i}$ for $i=1, \ldots, p$ and $H$ are $n \times n$ matrices, and $\varepsilon_{t}$ a vector of $n$ structural shocks. Equation 1 can be rewritten with lag-operator notation in a compact representation as

$$
A(L) Y_{t}=H \varepsilon_{t},
$$

where $A(L)=I_{n}-A_{1} L-\ldots-A_{p} L^{p}$. We assume that the lag order $p$ is known and that the $\operatorname{det}(A(z))$ has all roots outside the unit circle so that the data generating process is invertible. This equation characterizes all dynamics of the observable time-series variables in the model. The structural shocks are assumed to be uncorrelated at all leads and lags.

We are interested in disentangling the policy/feedback rule and monetary policy shocks. In other words, we want to study the effect of monetary policy surprises on the dynamics of the observable series $Y_{t}$. The column $j$ of matrix $H$ provides the contemporaneous effect of a change in structural shock $j$ on each variable in $Y_{t}$. Following Stock and Watson (2012) notation, we assume that the monetary policy shock corresponds to the first column of $H$ and we denote it as $H_{1}$.

The impulse response function (IRF) of $Y_{t}$ with respect to a monetary policy shock is then given by

$$
\frac{\partial Y_{t}}{\partial \varepsilon_{1 t}}=A(L)^{-1} H_{1}
$$

The parameters $A(L)^{-1}$ can be identified directly from equation 1 with $H \varepsilon_{t}=\eta_{t}$ innovations, which we can estimate via ordinary least squares. However, $H_{1}$ remains to be identified. To identify the monetary policy shocks, $H_{1}$, we use the external instrument based on high-frequency identifi- 
cation of shocks approach as in Gertler and Karadi (2015), which combines the external instrument approach to identification of structural shocks as in Stock and Watson (2012) and Mertens and Ravn (2013) with high frequency event studies around monetary policy announcements as in Kuttner (2001), Gurkaynak et al. (2005), Hamilton (2008), and Campbell et al. (2012).

We need an external instrument, $Z_{t}$, that fulfills the following assumptions:

1. Relevance: $E\left(\varepsilon_{1 t} Z_{t}\right)=\alpha \neq 0$

2. Exogeneity: $E\left(\varepsilon_{j t} Z_{t}\right)=0, j=2, \ldots, n$

These two assumptions show that a valid set of instruments must be correlated with the structural monetary policy shock, but not with other structural shocks. As in Gertler and Karadi (2015), we use changes in the three-month-ahead monthly federal funds futures around a monetary policy announcement as a valid instrument. The difference before and after a policy announcement represents the change in the expectations of financial market participants due to an unanticipated monetary policy action. The main concept behind using an external instrument is that, when regressing the VAR innovations $\eta_{t}$ on the instrument $Z_{t}$, the fitted value of the regression identifies the structural shock up to its sign and scale. Further details on the derivation of structural shocks using external instruments are presented in Stock and Watson (2012), Mertens and Ravn (2013), and Gertler and Karadi (2015). ${ }^{1}$

\subsection{Data, Lag Selection, and Statistical Inference}

To estimate the model described in the previous sub-section we used either five or six variables. These variables are a combination of a common set of four variables (industrial production, CPI, one-year Treasury rate, and excess bond premium, corresponding to the four variables used in the simple VAR model in Gertler and Karadi (2015)) with one or two more variables, which are chosen based on the question we are addressing. In most of our empirical applications we use monthly data, but in one of our analysis we use quarterly data due to data availability. The monthly data run from January 1983 to December 2017, while the quarterly data run from 1981:Q1 to 2017:Q4. In Tables 2 and 3 in the Appendix we describe all the data that we use.

\footnotetext{
${ }^{1}$ The Gertler and Karadi (2015) shock is not criticism free. Ramey (2016) argues that the shock may be unanticipated but not exogenous to the economy. As such, if the econometrician does not account for the Fed's private information about the state of the economy, the validity of the inference based on this shock may be limited. In addition, this shock also includes the so-called information shock, and therefore it is not a pure monetary policy shock; Jarocinski and Karadi (2018) tackle this issue.
} 
When using monthly data to estimate the SVAR model, we follow Gertler and Karadi (2015) and select the number of lags, $p$, in the SVAR model to be $12 .^{2}$ When using quarterly data to estimate the SVAR model, we use 4 lags to be consistent with the number of lags that we use in the estimation with monthly data.

A final, but very important, component of our methodology has to do with the way we make statistical inference. Following Brüggemann et al. (2016) and Jentsch and Lunsford (2016), who show that, in the presence of heteroskedasticity, it is incorrect to use a wild bootstrap method to estimate the distribution of impulse responses in the context of proxy SVARs, we use a moving block bootstrap method to estimate the distribution of impulse responses. ${ }^{3}$ The algorithm of the residual-based moving block bootstrap we use is the same as in Mertens and Olea (2018), which uses the same procedure as Jentsch and Lunsford (2016) but without the centering of the proxies in step 4 of their procedure. To initialize the algorithm we choose a block of length $\ell$ and compute the number of blocks $N=[T / \ell]$, where [.] rounds up to the nearest integer so that $N \ell \geq T{ }^{4}$ Next we collect the $n \times \ell$ blocks of the innovations $\eta_{t}$ and the proxy variable. Then, we independently draw $N$ integers with replacement from the set $\{1, \ldots, T-\ell+1\}$, placing equal probability on each element of the set, collect the blocks of residuals and proxies using the drawn integers as positional indexes, and we center the residuals to ensure that they have a zero-mean. New data are generated using the data generating process with the newly constructed residuals. Finally, we re-estimate the reduced VAR model parameters and $H_{1}$, and compute the impulse responses. We repeat this process 5000 times in order to get the distribution of impulse responses. From this distribution of impulse responses, we show the median impulse response and the $68 \%$ confidence bands. ${ }^{5}$

\section{The Effect of Monetary Policy Shocks on Housing Rents}

In this section we present the main result of the paper - the effect of monetary policy on housing rents -, provide an explanation for the result based on the effect on monetary policy shocks on

\footnotetext{
${ }^{2}$ Both the Akaike and Schwarz information criteria approaches suggest using 3 lags instead, but to be closer to the literature, we chose to use 12 lags. Nevertheless, we conducted a robustness analysis with 3 lags, and the results remain unchanged.

${ }^{3}$ We note that, as discussed in Mertens et al. (2018), there are other alternative methods to estimate the distribution of impulse responses in the context of SVARs that are also asymptotically consistent. While all our results are based on a moving block bootstrap method, we also implemented the Delta method and a parametric bootstrap described in Montiel-Olea et al. (2016), and the results obtained with these methods are in line with those obtained using the moving block bootstrap method.

${ }^{4}$ We pick the length of the block using $\ell=5.03 T^{1 / 4}$ as in Jentsch and Lunsford (2016).

${ }^{5}$ See Jentsch and Lunsford (2016) for a more detailed description of the algorithm as well as for theoretical results concerning the consistency of the moving block bootstrap procedure.
} 
housing tenure decisions, and show that the response of rents is different from that of the prices of goods or other services.
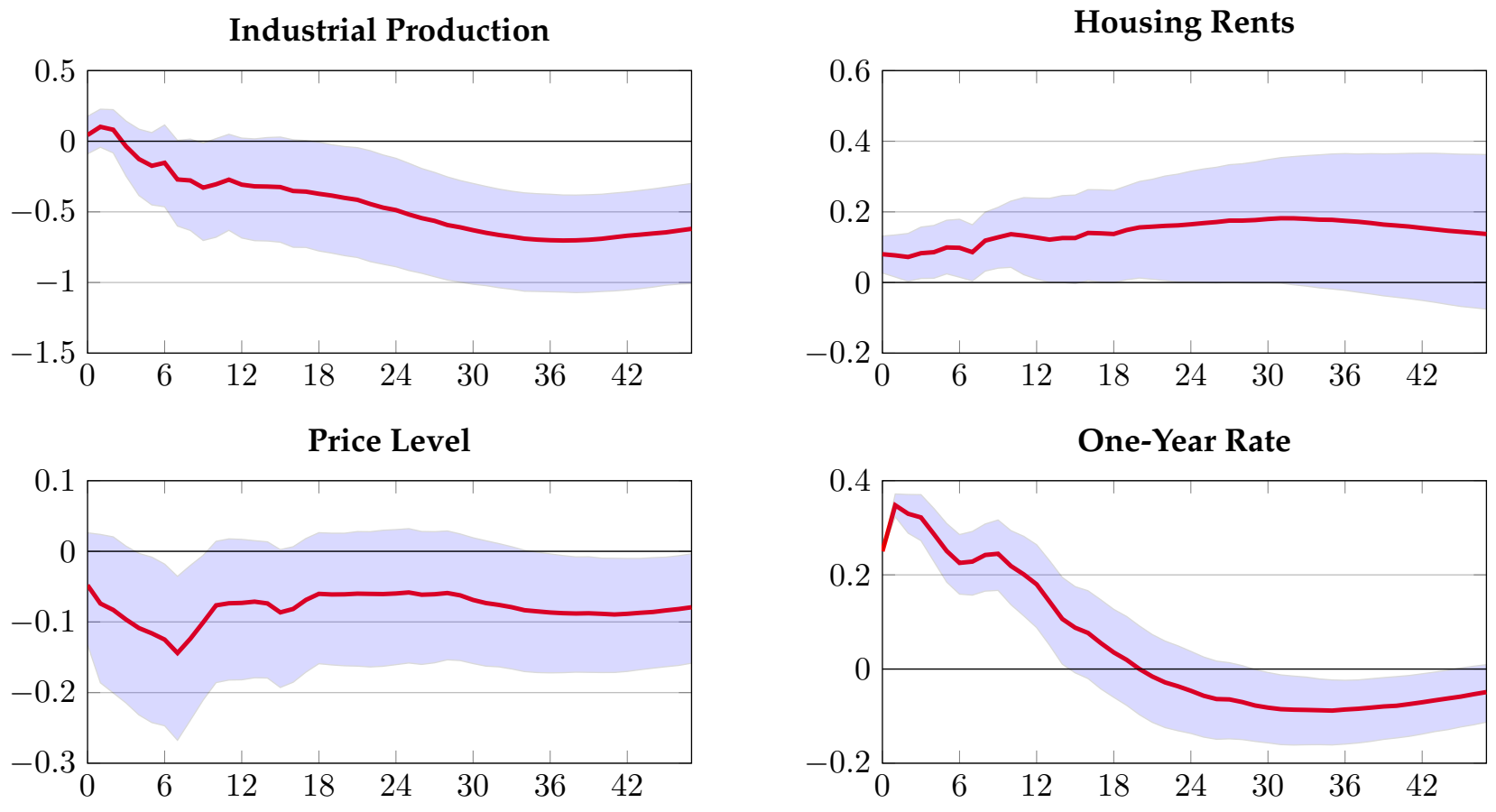

Excess Bond Premium

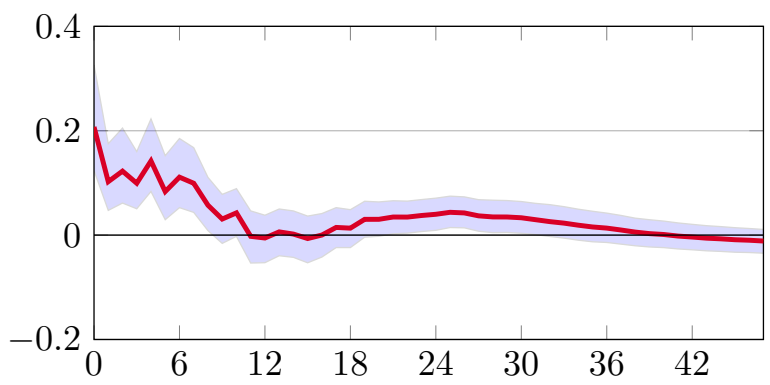

Figure 1: Baseline results: percentage responses of the baseline model variables to a 25 bps monetary policy shock identified with high-frequency surprises on federal funds 3-month futures around policy meetings. The red line corresponds to the median response and the shaded areas correspond to $68 \%$ confidence bands, which were computed using a moving block bootstrap method. The first-stage regression F-test has a value of 18.29 , and its robust $R^{2}$ is $5.27 \%$.

Figure 1 shows the IRFs of a 25 basis point (bps) monetary policy shock on the four core variables and on housing rents. The IRFs of industrial production, CPI, one-year Treasury rate, and excess bond premium are standard and well known. ${ }^{6}$ The novel result pertains to the response of nominal housing rents to a monetary policy shock. In contrast to the prices of goods or other

\footnotetext{
${ }^{6}$ In the case of the CPI, the result is standard for this identification of monetary policy shocks; however, as we show in the next section, with other identifications of monetary policy shocks, it is still common to observe a slight increase of prices before they start to decline, a result known in the literature as the "price puzzle" (Sims (1992)).
} 
services, nominal housing rents increase in response to a contractionary monetary policy shock. ${ }^{7}$ Note that this result implies that real housing rents (defined as the ratio of nominal housing rents to consumer prices) also increase in response to a contractionary monetary policy shock, but by more than nominal housing rents. ${ }^{8}$ This finding is surprising because nominal housing rents are the price of a service - shelter - and, from standard monetary theory, it would be expected that all nominal prices should decline (or at least not increase) after a contractionary monetary policy shock. For instance, if rents were very sticky, it would follow that nominal rents would not change (or would change at a lower rate than other goods) and that, as other nominal consumer prices fall, real housing rents would increase. Our results show, however, that this mechanism cannot be at play because nominal rents react quickly, which in turn implies that there must be a strong reaction in real terms of the housing rental market.

One possible explanation for this result is that the monetary shocks are not well identified, and therefore the response of housing rents to monetary policy shocks shown in Figure 1 is spurious. This explanation seems implausible because the IRFs of the other four variables included in the SVAR model behave as expected. ${ }^{9}$ Moreover, the identification of monetary policy shocks that we follow is the same as that used in Gertler and Karadi (2015), which is a well-established method in this literature.

An alternative explanation is that monetary policy affects housing tenure decisions - own versus rent. If both the supply of housing for rental and of housing for ownership are inelastic in the short run, and there is limited convertibility between homes for sale and homes for rent, when interest rates go up, mortgage rates rise and the cost of homeownership increases. As homeownership costs rise, the demand for rental housing also increases, and, as a result, housing rents rise. To test this hypothesis we use the SVAR model described in the previous section to estimate the response of housing prices, the housing stock for renting vacancy rate, and the homeownership rate to a contractionary monetary policy shock. The results of this exercise are shown in Figure 2 and are all based on quarterly data, because the homeownership rate and the housing stock for renting vacancy rate data are only available at that frequency. We also re-estimated the response of hous-

\footnotetext{
${ }^{7}$ Following the results of Gertler and Karadi (2015), we chose to use the three-month-ahead forward federal funds rate as the instrument for monetary policy, as it has the best statistical properties among the instruments analyzed in Gertler and Karadi (2015). However, we also experimented with other instruments and our main results held.

${ }^{8}$ In Figure 8 in the Appendix, we show that indeed real housing rents also increase in response to a contractionary monetary policy shock, but we do not formally test whether the response of nominal housing rents is statistically different from that of real housing rents.

${ }^{9}$ We note that our results with respect to the response of rents to monetary policy shocks are, overall, robust to using different approaches to identify monetary policy shocks and to different sample periods.
} 
ing rents using quarterly data. ${ }^{10}$ In line with our hypothesis that monetary policy affects housing tenure decisions, the results in Figure 2 show that, in response to a contractionary monetary policy shock, housing rents increase and housing prices, the homeownership rate, and the housing stock available for rent decline.
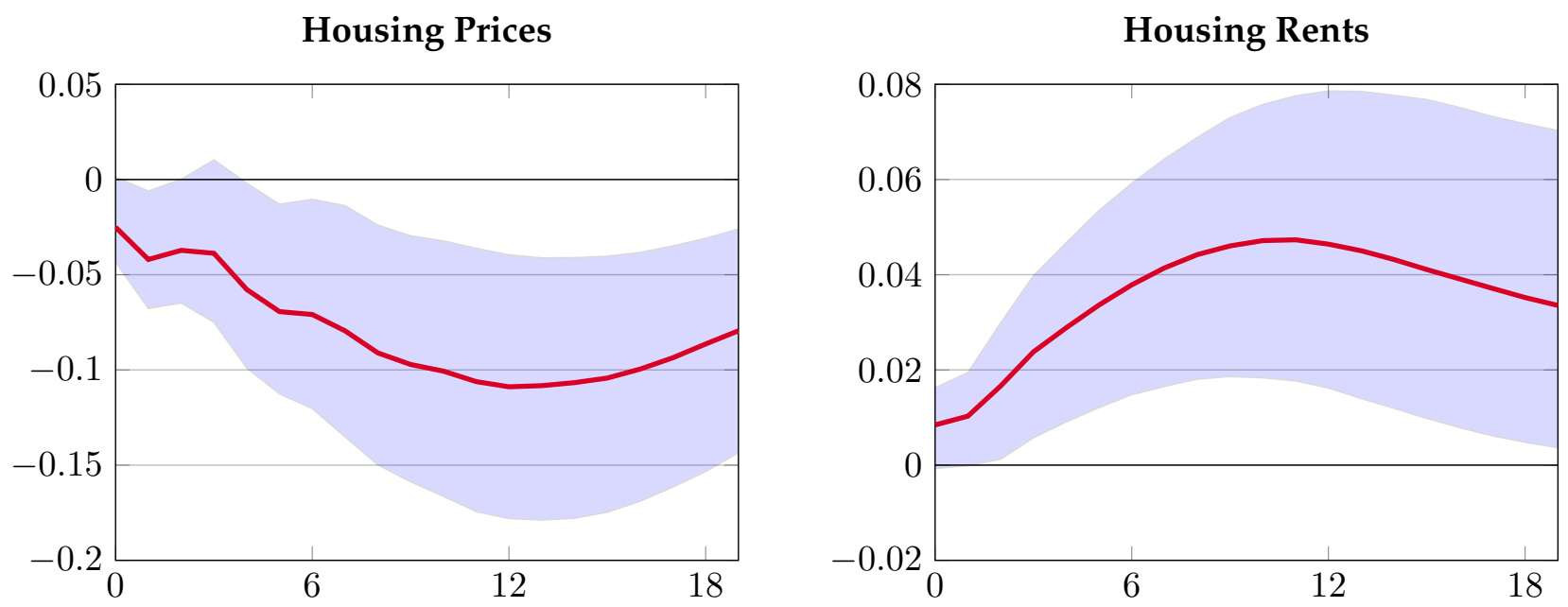

Housing Stock for Renting Vacancy Rate
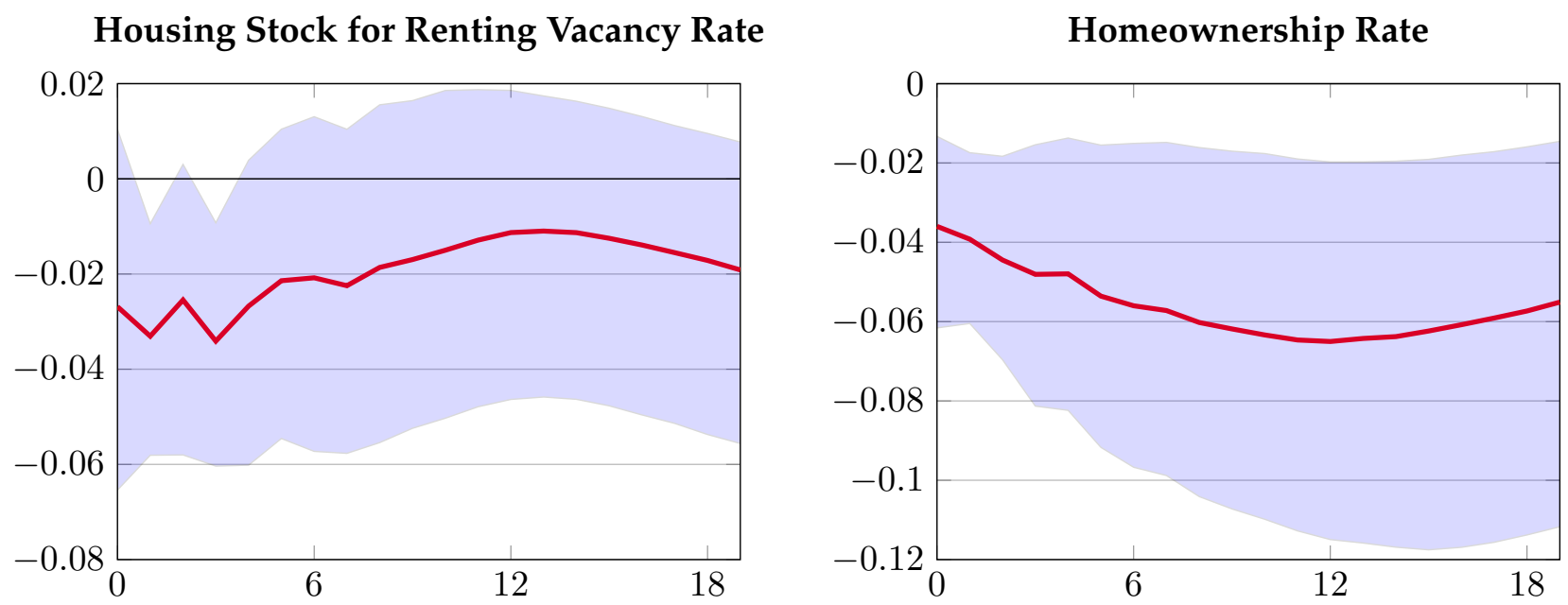

Figure 2: Testing the housing tenure choice channel: percentage responses of selected variables of the proxy svar model to a 25 bps shock in the federal funds rate. The red line corresponds to the median response and the shaded areas correspond to $68 \%$ confidence bands, which were computed using a moving block bootstrap method.

So far, we have shown only that housing rents increase in response to a contractionary monetary policy shock; however, housing rents are only a small portion of the total consumer consumption bundle and the overall CPI. A natural question is whether other components of the CPI behave

\footnotetext{
${ }^{10}$ Each panel in Figure 2 is obtained by estimating an SVAR model with a common set of four variables (industrial production, CPI, one-year Treasury rate, and excess bond premium) and an additional variable (either housing prices, housing rents, housing stock for renting vacancy rate, or the homeownership rate).
} 
similarly to housing rents. In Figure 3, we show the IRFs of the main components of the CPI. The first three variables - rent of primary residence (same as housing rent), owners' equivalent rent (OER), and shelter (the combination of rents and the OER) - are all part of the housing component of the CPI, while the other six variables - food and beverages, transportation, apparel, medical care, education and communication, and recreation - are the remaining major components of the CPI. ${ }^{11,12}$

The first row of Figure 3 shows that not only housing rents rise after a contractionary monetary policy shock, but also the OER, and, consequently, shelter, which we define as the combination of housing rents and the OER. As for the other major components of the CPI, the results show that prices either decrease (food and beverages and transportation) or have no reaction to a monetary policy shock (apparel, medical care, education and communication, and recreation). ${ }^{13}$

The fact that the OER behaves similarly to housing rents should not be surprising, as the OER is an estimate of homeowners' rents that uses housing rents as an input. However, the fact that two sub-components of the CPI that account for about one-third of the total CPI increase after a contractionary monetary policy shock raises the question of the importance of housing for inflation dynamics. We tackle this question in the next section.

\section{Shelter Costs and Inflation Dynamics}

In this section, we study the implications of the dynamics of shelter costs (rents and the OER) for inflation dynamics. We start by describing how the shelter costs component of the CPI or PCE is constructed, compare some of the statistical properties of the widely used measures of inflation (the CPI and the PCE) with those of alternative measures of inflation that exclude shelter costs, compare the responses to monetary policy shocks of inflation measures including and excluding shelter costs, and end by evaluating the importance of the response of shelter to monetary shocks for the "price puzzle".

\footnotetext{
${ }^{11}$ In the next section we discuss in some detail the concept of owners' equivalent rent and how it is constructed by the BLS.

${ }^{12}$ Our definition of shelter costs is slightly different from that of the BLS, as we consider only the rent of primary residence and the OER components, while the BLS also includes costs for lodging away from home. Because the weight of such costs is only about $1 \%$, for practical purposes, there is no relevant difference between our measure of shelter costs and that of the BLS.

${ }^{13}$ We note that, when the Delta and the parametric bootstrap methods are used to estimate the distribution of IRFs, the responses of rents, OER, and shelter are statistically significant for most time horizons. At the same time, similar to what we show in Figure 3, for the other components of the CPI we find that the response of these items to a monetary shock is not statistically significant for all time horizons.
} 
Housing Rents

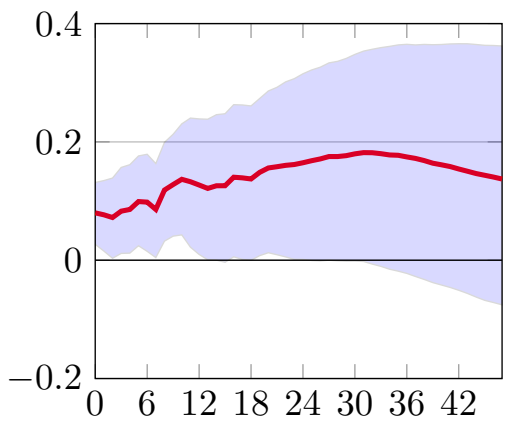

Food and Beverages

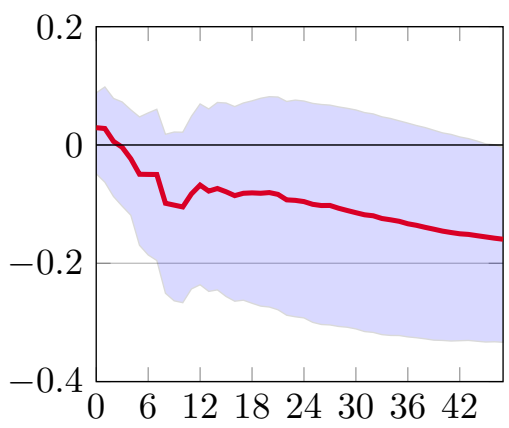

Medical Care

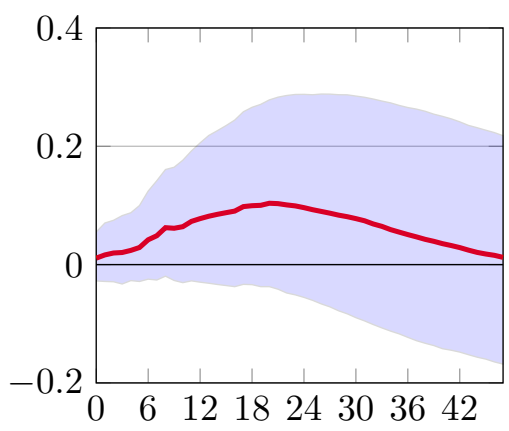

Owners' Equivalent Rent

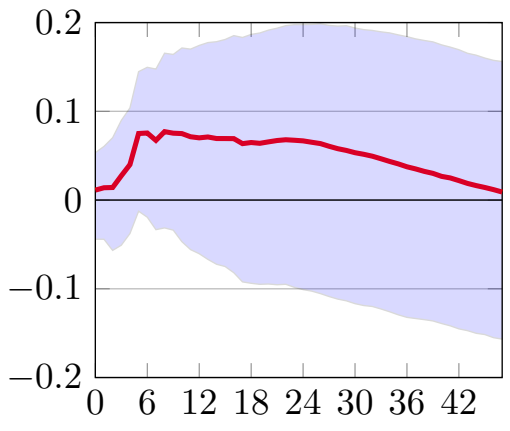

Transportation

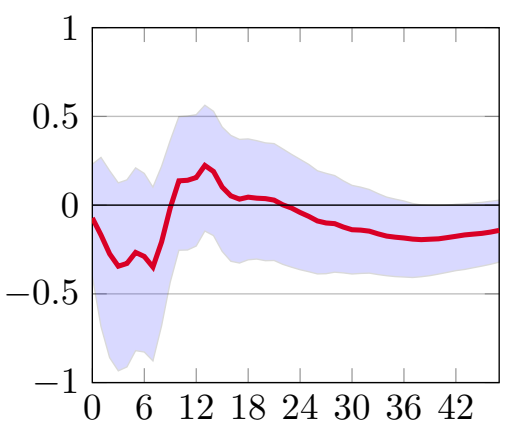

Recreation

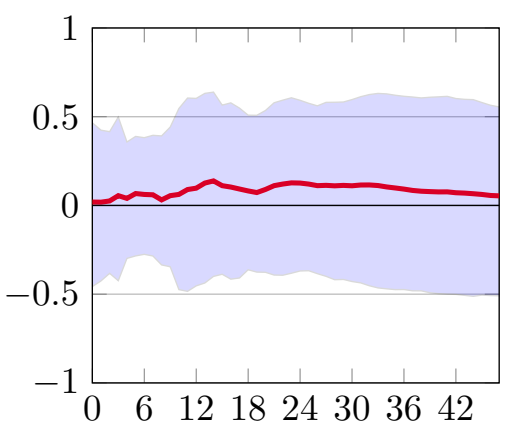

Shelter

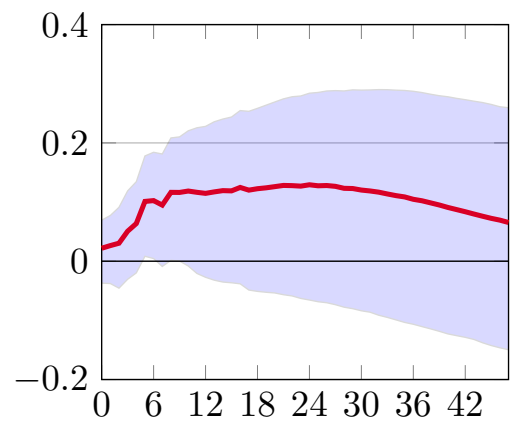

Apparel

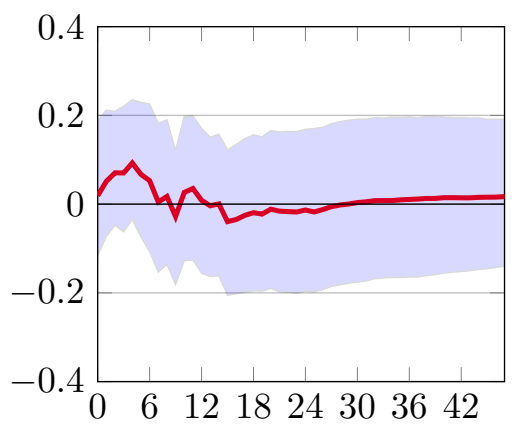

Education and Communication

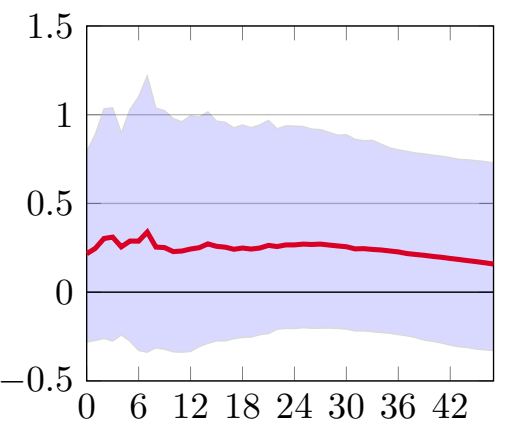

Figure 3: Response of the main components of the CPI to a monetary policy shock: percentage responses of selected variables of the proxy svar model to a 25 bps shock in the federal funds rate. The red line corresponds to the median response and the shaded areas correspond to $68 \%$ confidence bands, which were computed using a moving block bootstrap method.

\subsection{Shelter Costs in Measures of Inflation}

Housing expenses are the largest component of the CPI, with a total weight of $42 \%$ in the index. This component has two sub-components: shelter and other housing-related expenses, with the former currently weighing around 33\% in the total CPI and the latter about 9\%. The fact that shelter costs have such a large weight in the overall CPI suggests that the index will be very sensitive to what happens in this component. As for the PCE, housing expenses are also its largest component; 
however, the weight is smaller than in the CPI, as such expenses account for only close to $24 \%$ of the index, and shelter is only $16 \%$ of the overall index - about half of the weight of shelter in the CPI. Given the lower weight of shelter costs, we expect the PCE to be less sensitive to changes in shelter costs than the CPI.

Although the prices of most of the sub-components of housing (e.g., rent of primary residence, utilities, or insurance) are relatively easy to measure, the price of shelter for homeowners is not, because it is not a market price. Before 1983, the BLS used house prices, mortgage interest rates, property taxes, insurance, and maintenance costs to estimate shelter costs for homeowners. Because not all of these items represent costs for a homeowner, in 1983, the BLS changed its approach and began using the concept of OER to estimate the rental cost for homeowners. The OER is an estimate of the rent that a homeowner would have to pay if he or she was renting that same home. To compute the OER, the BLS uses observed rents and the characteristics of the homes being rented as inputs to the method. ${ }^{14}$ As a result, the correlation between the year-on-year growth rate of the two series is very high - close to $85 \%$. For this reason, we consider rent of primary residence and the OER to be basically the same, and, from here on, we analyze only shelter costs.

\subsection{Inflation Measures Net of Shelter Costs}

One way to understand the importance of shelter costs for inflation dynamics is by considering alternative measures of inflation that exclude shelter costs. In Figures 4 and 5, we show the level and the month-to-month growth rates of (1) the CPI and the CPI net of shelter and (2) the PCE and the PCE net of shelter, while in Table 1, we provide some descriptive statistics.

Table 1: Inflation indexes descriptive statistics.

\begin{tabular}{rrrrrr}
\hline & mean & s.d. & $\rho_{1}: x_{t}, x_{t-1}$ & $\rho_{2}: x_{t}, x_{t-2}$ & ADF $^{a}$ \\
\hline CPI & 0.22 & 0.25 & 0.44 & 0.06 & -7.35 \\
CPI net of shelter & 0.19 & 0.39 & 0.44 & 0.08 & -7.37 \\
PCE & 0.19 & 0.19 & 0.43 & 0.14 & -6.70 \\
PCE net of shelter & 0.17 & 0.23 & 0.44 & 0.15 & -6.90 \\
\hline
\end{tabular}

${ }^{a}$ ADF is Augmented Dicky-Fuller

\footnotetext{
${ }^{14}$ For more details on how the BLS constructs the rent of primary residence and the OER, see Bureau of Labor Statistics (2009)
} 
CPI vs CPI net of shelter

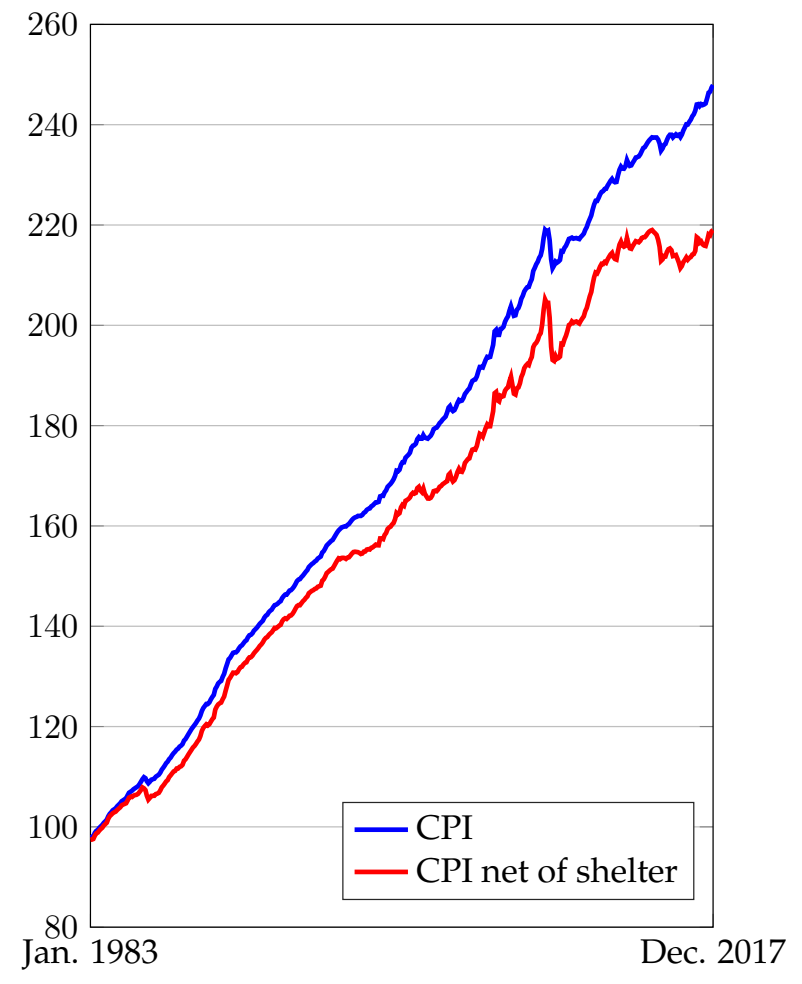

PCE vs PCE net of shelter

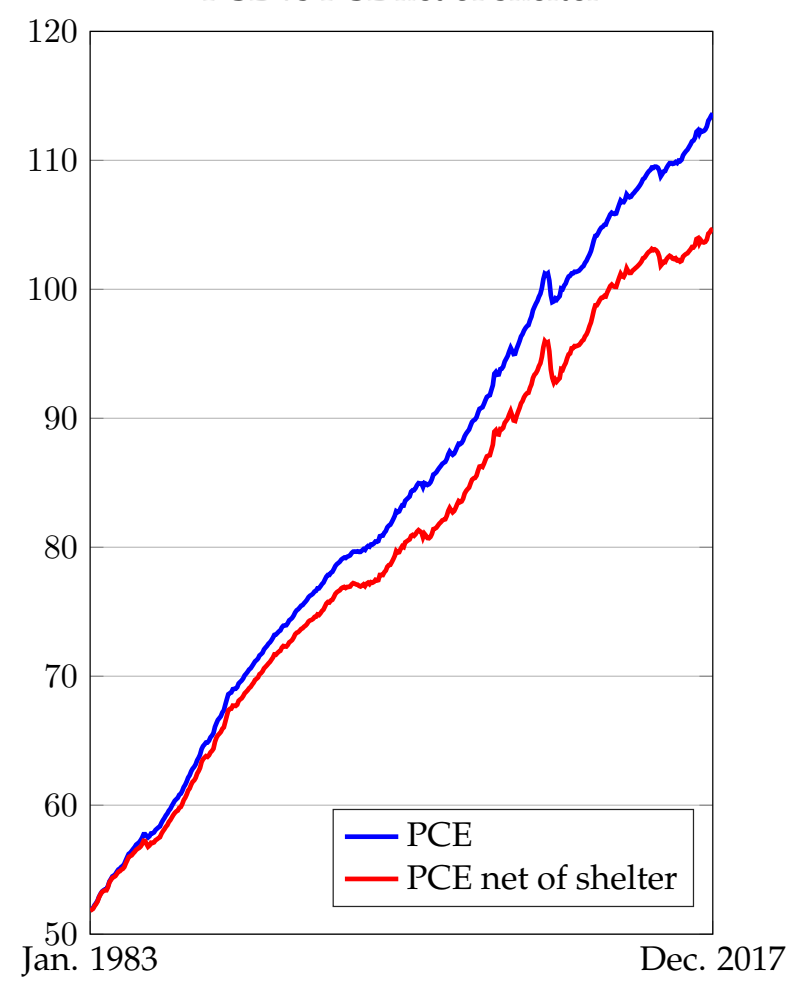

Figure 4: Monthly index time series of CPI vs. CPI net of shelter, and PCE vs. PCE net of shelter from January 1983 to December 2017.

The visual inspection of Figures 4 and 5 suggests that the price indexes with and without shelter costs are not too different from each other. The most noticeable difference is that the price measures including shelter costs increased at a slightly faster pace than those excluding such costs, as the blue lines in Figure 4, corresponding to the overall price indexes, are always above the red lines, corresponding to the price indexes excluding shelter costs. In addition, Figure 5 suggests that the overall price indexes are less volatile than the price indexes excluding shelter costs. The entries in Table 1 confirm that indeed the price indexes with and without shelter costs have similar statistical characteristics, but the measures including shelter increased more on average between 1983 and 2017 and that they are less volatile. Despite some small differences in the mean and the standard deviation, the two pairs of inflation measures show remarkably similar autocorrelation structures the first- and second-order autocorrelation terms are almost identical, and all series are stationary.

Although the two pairs of variables are very similar in several dimensions (as shown in Figures 4 and 5 and Table 1), we are interested in knowing whether these variables respond differently to monetary shocks. The left-hand panels of Figure 6 show the IRFs of (1) the CPI and the CPI net of shelter and (2) the PCE and the PCE net of shelter; while the right-hand panels of the same figure 

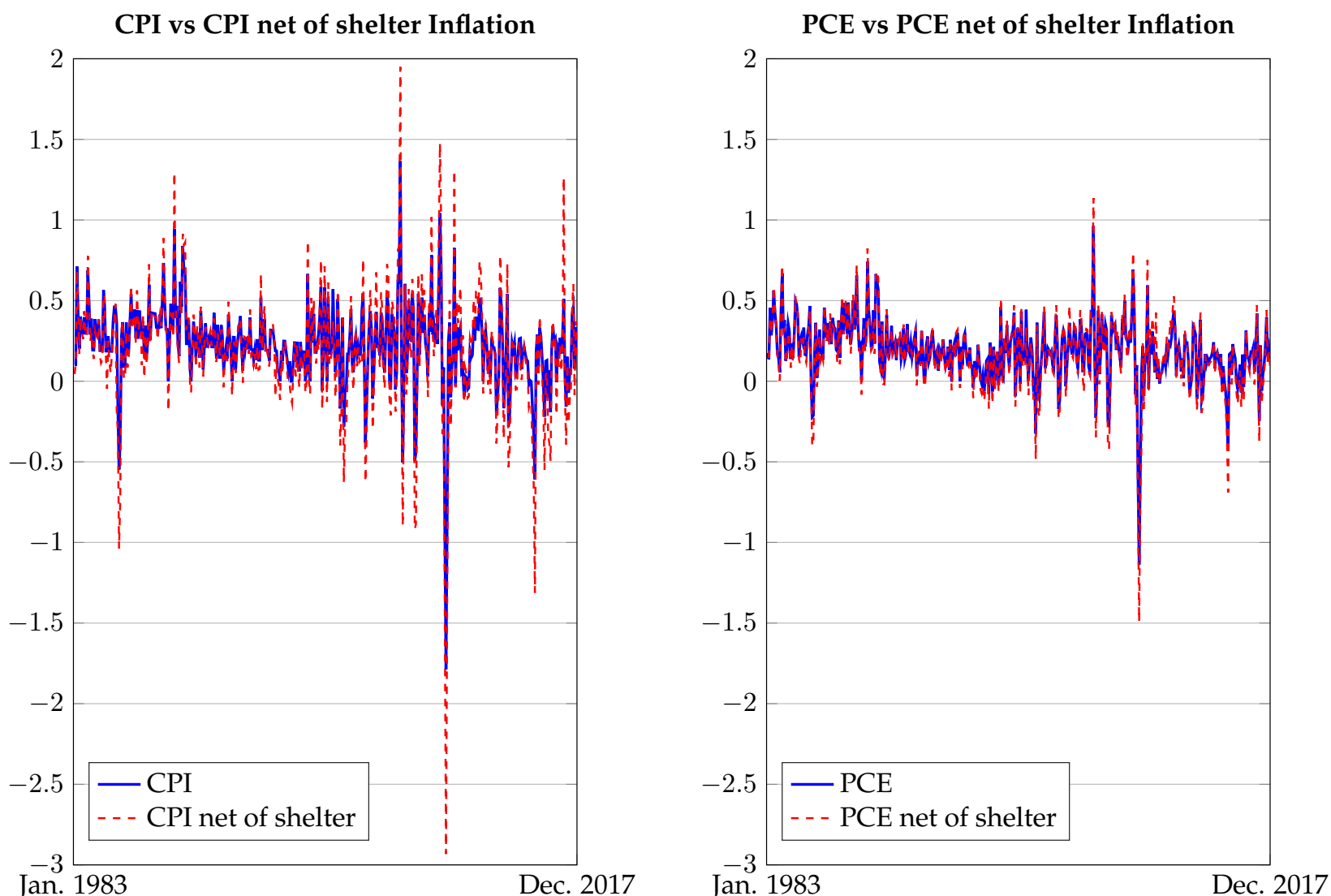

Figure 5: Monthly inflation time series of CPI vs. CPI net of shelter, and PCE vs. PCE net of shelter from January 1983 to December 2017.

show the difference between the impulse responses of (1) the CPI and CPI net of shelter and (2) the PCE and the PCE net of shelter. ${ }^{15}$ The results in Figure 6 show that the measures of inflation that exclude shelter react more to a monetary policy shock than the measures of inflation that include all items. Moreover, as shown in the right-side panels of Figure 6, the difference between the impulse responses of the two inflation measures is statistically significant. As expected, given the larger weight of shelter in the CPI, the difference is larger for the CPI than for the PCE; however, the difference is statistically significant in both cases.

A natural question is, why do these findings matter? First, by not taking into account the response of rents (vis-à-vis shelter) to monetary policy, monetary models will be missing an important element of the effect of monetary policy on prices, and therefore theory and data will not be well

\footnotetext{
${ }^{15}$ The results in Figure 6 are based on a proxy SVAR model with five variables — industrial production, one-year Treasury rate, excess bond premium, CPI (PCE), and CPI (PCE) net of shelter. We simultaneously include the CPI (PCE) and the CPI (PCE) net of shelter in the model to test if the impulse responses of the two inflation measures are statistically different. To compute the Wald-statistic of the hypothesis that the impulse responses of the CPI (PCE) and the CPI (PCE) net of shelter are statistically different, we bootstrap the difference between the impulse responses to the same monetary policy shock using a moving block bootstrap method.
} 


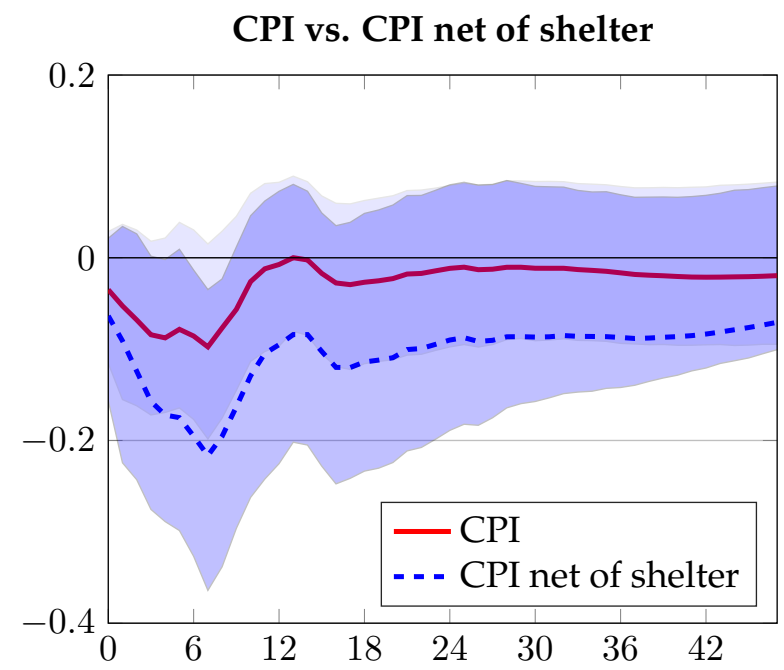

Difference: CPI vs. CPI net of shelter

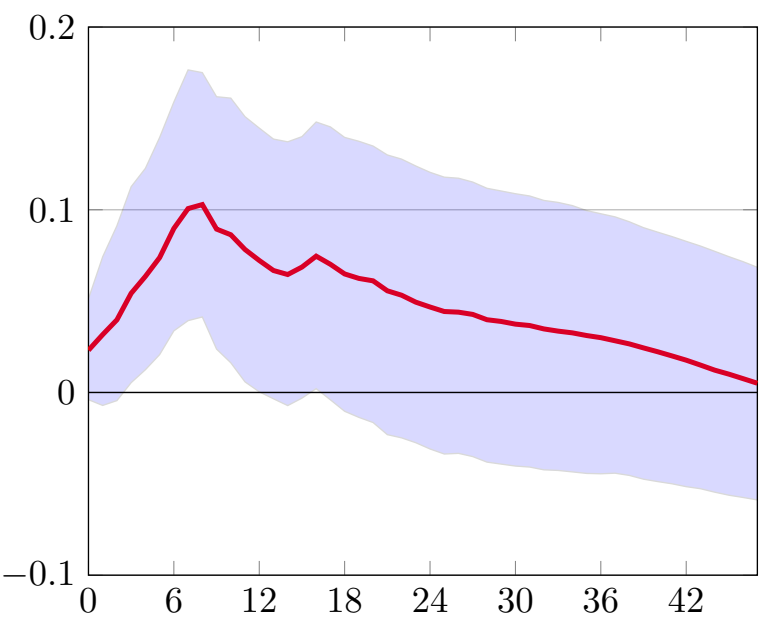

PCE vs. PCE net of shelter

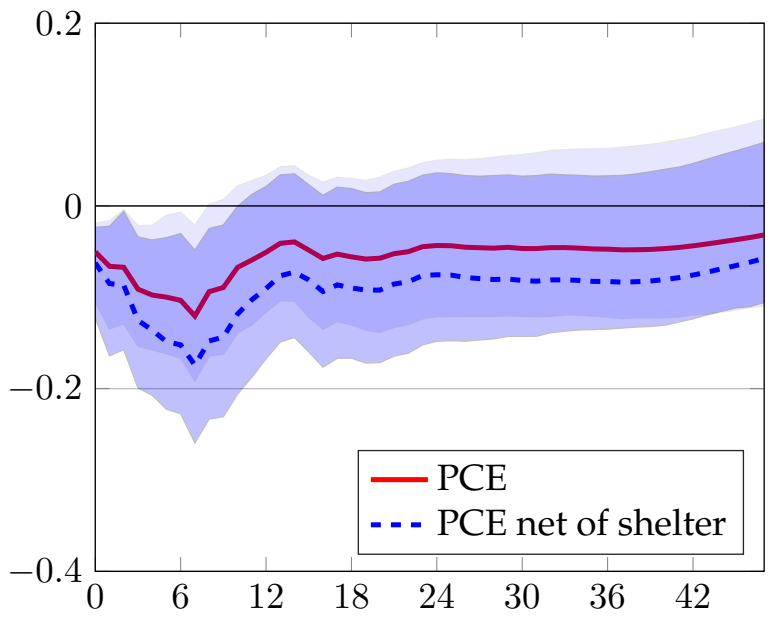

Difference: PCE vs. PCE net of shelter

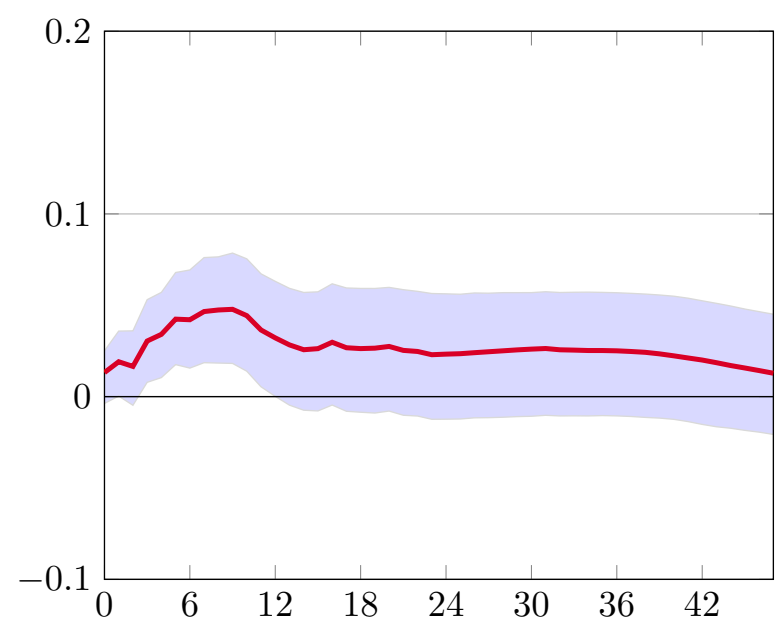

Figure 6: All-items inflation measures vs. net-of-shelter measures: percentage responses of the baseline model variables to a 25 bps monetary policy shock identified with high-frequency surprises on federal funds 3-month futures around policy meetings. The solid red and the dashed blue lines correspond to the median responses, while the shaded areas correspond to $68 \%$ confidence bands, which were computed using a moving block bootstrap method.

mapped. Second and more important, when monetary policy authorities target a measure of inflation like the CPI or the PCE, to produce the same change in inflation, monetary authorities will need larger monetary policy shocks, with resulting larger real effects and nominal price volatility. Given the results of this paper, looking at the total CPI or PCE reactions to monetary policy masks important heterogeneity in consumer price variation. We find that low responses of overall consumer prices to monetary policy shocks are the result of strong opposing movements in nominal housing rents and the nominal prices of all other goods and services in the economy. 
In addition, based on our results, the response of rents to monetary policy shocks is likely to be the result of a shift in demand between rental and owner-occupied homes. Therefore, the change in rents as a result of monetary policy shocks is a relative price movement and not a change in trend (or the underlying inflation rate). Monetary policy should react to changes in the trend of prices (inflation) but not to relative price changes. A measure of inflation that includes rents/shelter will likely lead monetary authorities that follow a monetary policy rule, such as the Taylor rule, to respond both to changes in inflation and to relative price movements.

\subsection{Housing Rents and the "Price Puzzle"}

One argument in favor of using the high-frequency instrument approach, as in Gertler and Karadi (2015), to identify monetary policy shocks is that, when this approach is used, there is no "price puzzle" - prices rising after a contractionary monetary policy shock. Our empirical results based on the high-frequency instrument approach confirm this finding. However, as we mentioned previously, the Gertler and Karadi (2015) shock is not criticism free, and some authors prefer using the Romer and Romer (2004) shock. One critique of Romer and Romer (2004) is that the response of prices to a contractionary monetary policy shock still exhibits a "price puzzle". In Figure 7, we compare the responses of prices including and excluding shelter for different methods of identifying monetary policy shocks; in addition to the high-frequency approach, we use a FAVAR model as in Bernanke et al. (2005) and the Romer and Romer (2004) monetary policy shocks as an instrument for the proxy SVAR described in section $2 .{ }^{16}$ We find that, for the high-frequency instrument case, the response of prices excluding shelter costs to a contractionary monetary policy shock is larger than that of price measures including shelter costs, and of the and Romer and Romer instrument case it turns negative much earlier in comparison to price measures including shelter costs. In the case of the FAVAR model, both the all-items CPI and PCE response show a large and positive response to a contractionary monetary policy shock, while the same price measures excluding shelter either do not show any response (the case of the CPI net of shelter) or have a very moderate positive response (the case of the PCE net of shelter).

Although we cannot claim that excluding shelter costs from price measures solves the "price puzzle", it greatly ameliorates the puzzle. In other words, the response of housing rents to monetary policy shocks does not fully account for the "price puzzle", but it goes a long way in explaining it.

\footnotetext{
${ }^{16}$ In the Appendix, we provide a brief description of the FAVAR model and details of the implementation of the model.
} 

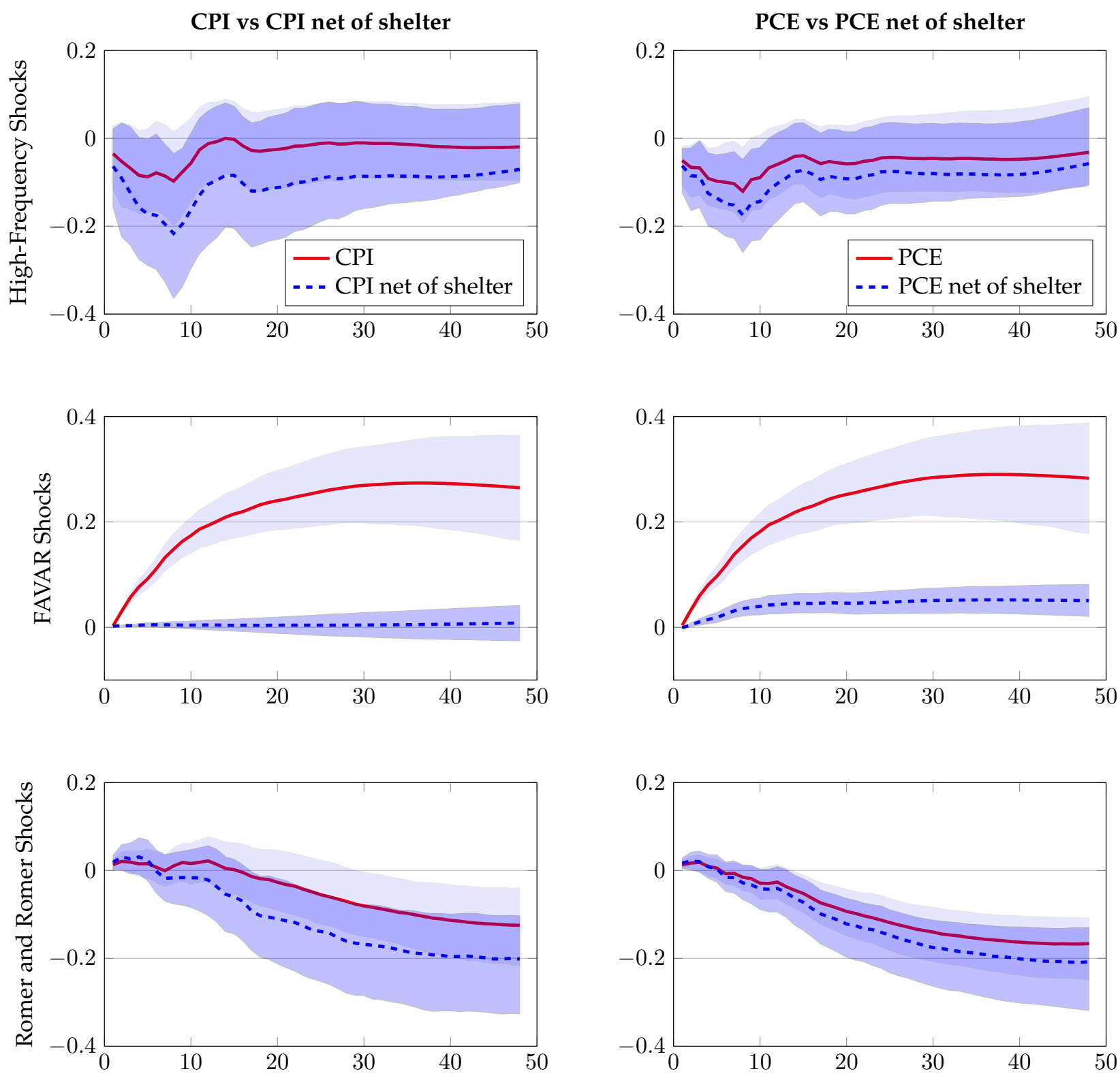

Figure 7: All-items inflation measures vs net-of-shelter measures: percentage responses of the consumer price indexes to a 25 bps monetary policy shock identified with high-frequency, FAVAR, and Romer and Romer (2004) shocks. The solid red and the dashed blue lines correspond to the median responses, while the shaded areas correspond to $68 \%$ confidence bands, which were computed using a moving block bootstrap for the high-frequency shocks, a two-step bootstrap for the FAVAR shocks, and a standard bootstrap for the Romer and Romer shocks.

\section{Concluding Remarks}

In this paper, we show that housing rents, in contrast to the prices of other services and goods, increase in response to a contractionary monetary policy shock. In addition, we show that this result extends to the shelter component of the CPI and the PCE, and that the responses of these 
price indexes to monetary shocks are attenuated by the response of shelter costs. We argue that it is important to take into account the response of shelter costs for three reasons: first, for the purpose of linking the measures of inflation in theoretical monetary models to the same measures in the data; second, to enable monetary authorities to avoid excess consumer price variation when conducting monetary policy; and third, to explain to a large extent the "price puzzle" found in the literature.

In future research, we plan to analyze the welfare effects of monetary policy in the context of housing tenure choice. In particular, we are interested in understanding whether monetary policy has different welfare effects on homeowners and renters and whether the monetary authority should consider these effects when setting monetary policy.

\section{References}

Bernanke, B. S., Boivin, J., and Eliasz, P. (2005). Measuring the effects of monetary policy: A factor-augmented vector autoregressive (FAVAR) approach. Quarterly Journal of Economics, 120(1):387-422.

Brüggemann, R., Jentsch, C., and Trenkler, C. (2016). Inference in vars with conditional heteroskedasticity of unknown form. Journal of Econometrics, 191(1):69-85.

Bureau of Labor Statistics (2009). How the CPI measures price change of owner's equivalent rent of primary residence (OER) and rent of primary residence (Rent). Technical report.

Calza, A., Monacelli, T., and Stracca, L. (2013). Housing finance and monetary policy. Journal of the European Economic Association, 11(s1):101-122.

Campbell, J. R., Evans, C. L., Fisher, J. D., and Justiniano, A. (2012). Macroeconomic effects of federal reserve forward guidance. Brookings Papers on Economic Activity, 2012(1):1-80.

Debortoli, D., Kim, M. J., Lindé, J., and Nunes, M. R. C. (2017). Designing a simple loss function for central banks: Does a dual mandate make sense? International Monetary Fund.

Del Negro, M. and Otrok, C. (2007). 99 Luftballons: Monetary policy and the house price boom across U.S. states. Journal of Monetary Economics, 54(7):1962-1985.

Erceg, C. J., Henderson, D. W., and Levin, A. T. (2000). Optimal monetary policy with staggered wage and price contracts. Journal of Monetary Economics, 46(2):281-313.

Forni, M., Giannone, D., Lippi, M., and Reichlin, L. (2009). Opening the black box: Structural factor models with large cross sections. Econometric Theory, 25(5):1319-1347. 
Gertler, M. and Karadi, P. (2015). Monetary policy surprises, credit costs, and economic activity. American Economic Journal: Macroeconomics, 7(1):44-76.

Giannone, D., Reichlin, L., and Sala, L. (2004). Monetary policy in real time. NBER Macroeconomics Annual, 19:161-200.

Gilchrist, S. and Zakrajek, E. (2012). Credit spreads and business cycle fluctuations. American Economic Review, 102(4):1692-1720.

Gurkaynak, R. S., Sack, B., and Swanson, E. T. (2005). Do actions speak louder than words? The response of asset prices to monetary policy actions and statements. International Journal of Central Banking, 1(1):55-93.

Hamilton, J. D. (2008). Daily monetary policy shocks and new home sales. Journal of Monetary Economics, 55(7):1171-1190.

Iacoviello, M. (2005). House prices, borrowing constraints, and monetary policy in the business cycle. American Economic Review, 95(3):739-764.

Jarocinski, M. and Karadi, P. (2018). Deconstructing monetary policy surprises: the role of information shocks. ECB Working Paper Series 2133, European Central Bank.

Jentsch, C. and Lunsford, K. (2016). Proxy svars: asymptotic theory, bootstrap inference, and the effects of income tax changes in the united states.

Kuttner, K. N. (2001). Monetary policy surprises and interest rates: Evidence from the fed funds futures market. Journal of Monetary Economics, 47(3):523 - 544.

Luciani, M. (2015). Monetary policy and the housing market: A structural factor analysis. Journal of Applied Econometrics, 30(2):199-218.

McCracken, M. W. and Ng, S. (2016). Fred-md: A monthly database for macroeconomic research. Journal of Business \& Economic Statistics, 34(4):574-589.

Mertens, K. and Olea, J. . L. M. (2018). Marginal tax rates and income: New time series evidence. Quarterly Journal of Economics, forthcoming.

Mertens, K. and Ravn, M. O. (2013). The dynamic effects of personal and corporate income tax changes in the United States. American Economic Review, 103(4):1212-47.

Mertens, K., Ravn, M. O., et al. (2018). The dynamic effects of personal and corporate income tax changes in the united states: Reply to jentsch and lunsford. Technical report.

Montiel-Olea, J. L., Stock, J. H., and Watson, M. W. (2016). Uniform inference in svars identified with external instruments. Manuscript, Columbia University. 
Onatski, A. (2010). Determining the number of factors from empirical distribution of eigenvalues. The Review of Economics and Statistics, 92(4):1004-1016.

Piazzesi, M. and Schneider, M. (2016). Housing and macroeconomics. NBER Working Papers 22354, National Bureau of Economic Research.

Pivetta, F. and Reis, R. (2007). The persistence of inflation in the United States. Journal of Economic Dynamics and Control, 31(4):1326-1358.

Ramey, V. A. (2016). Macroeconomic shocks and their propagation. In Handbook of Macroeconomics, volume 2, pages $71-162$. Elsevier.

Romer, C. D. and Romer, D. H. (2004). A new measure of monetary shocks: Derivation and implications. American Economic Review, 94(4):1055-1084.

Sims, C. A. (1992). Interpreting the macroeconomic time series facts: The effects of monetary policy. European economic review, 36(5):975-1000.

Stock, J. H. and Watson, M. W. (2005). Implications of dynamic factor models for VAR analysis. NBER Working Papers 11467, National Bureau of Economic Research.

Stock, J. H. and Watson, M. W. (2012). Disentangling the channels of the 2007-2009 recession. NBER Working Papers 18094, National Bureau of Economic Research.

Stock, J. H. and Watson, M. W. (2016). Dynamic factor models, factor-augmented vector autoregressions, and structural vector autoregressions in macroeconomics. In Handbook of Macroeconomics, volume 2, pages 415-525. Elsevier.

Woodford, M. (2000). Interest and prices. Manuscript, Princeton University. 


\section{A Additional Figures}
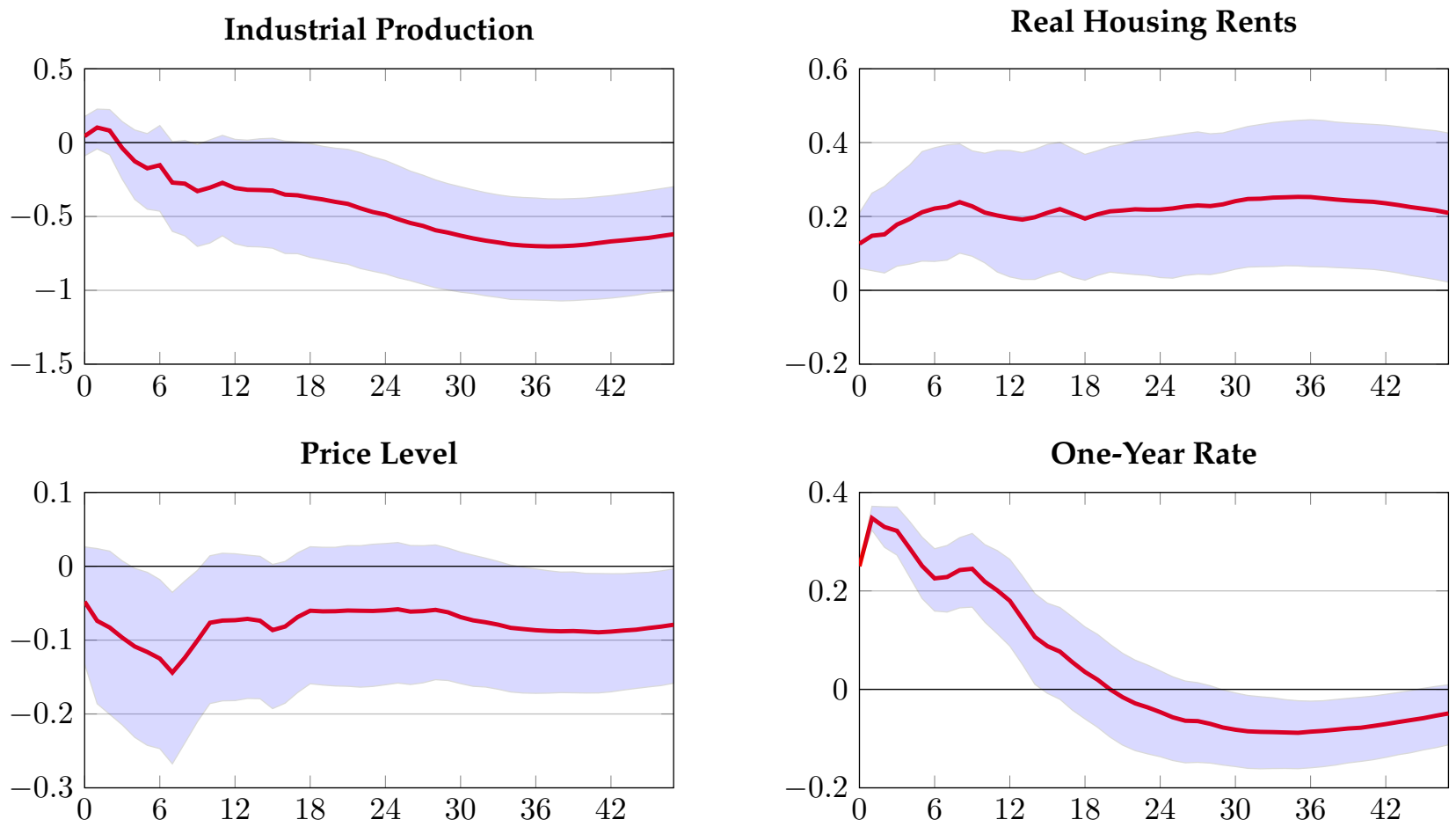

\section{Excess Bond Premium}

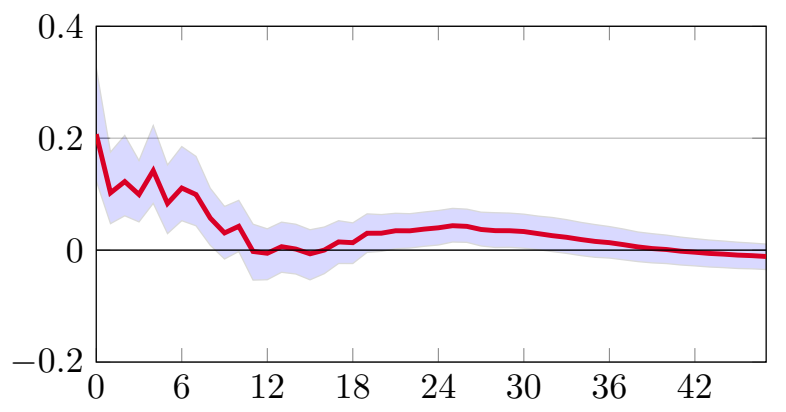

Figure 8: Additional results: percentage responses of the baseline model variables to a 25 bps monetary policy shock identified with high-frequency surprises on federal funds 3-month futures around policy meetings. The red line corresponds to the median response and the shaded areas correspond to $68 \%$ confidence bands, which were computed using a moving block bootstrap method. We use the all-items CPI to deflate the nominal housing rents. The first-stage regression F-test has a value of 18.29 , and its robust $R^{2}$ is $5.27 \%$. 


\section{B Data Used}

Table 2: Monthly Data Description

\begin{tabular}{|c|c|c|c|}
\hline Series & Source & Series Description & Sample \\
\hline Industrial Production (INDPRO) & FRED & Index $2012=100$, Seasonally Adjusted & 1983:M1 - 2017:M12 \\
\hline Housing Rents (CUSR0000SEHA) & FRED & $\begin{array}{l}\text { Consumer Price Index for All Urban Con- } \\
\text { sumers: Rent of primary residence, Index 1982- } \\
\text { 1984=100, Seasonally Adjusted }\end{array}$ & 1983:M1 - 2017:M12 \\
\hline Price Level (CPIAUCSL) & FRED & $\begin{array}{l}\text { Consumer Price Index for All Urban Con- } \\
\text { sumers: All Items, Index 1982-1984=100, Sea- } \\
\text { sonally Adjusted }\end{array}$ & 1983:M1 - 2017:M12 \\
\hline One-Year Rate (GS1) & FRED & $\begin{array}{l}\text { 1-Year Treasury Constant Maturity Rate, Per- } \\
\text { cent, Not Seasonally Adjusted }\end{array}$ & 1983:M1 - 2017:M12 \\
\hline Excess Bond Premium & $\begin{array}{l}\text { Jarocinski and } \\
\text { Karadi (2018) }\end{array}$ & Gilchrist and Zakrajek (2012) & 1983:M1 - 2017:M12 \\
\hline $\begin{array}{l}\text { Owners' Equivalent Rent } \\
\text { (CUSR0000SEHC) }\end{array}$ & FRED & $\begin{array}{l}\text { Consumer Price Index for All Urban Con- } \\
\text { sumers: Owners' equivalent rent of residences, } \\
\text { Index Dec } 1982=100 \text {, Seasonally Adjusted }\end{array}$ & 1983:M1 - 2017:M12 \\
\hline Shelter & Own calculation & $\begin{array}{l}\text { Average of rents and owners' equivalent rent } \\
\text { appropriately weighted by the corresponding } \\
\text { CPI weights, Index Dec } 1982=100 \text {, Seasonally } \\
\text { Adjusted }\end{array}$ & 1983:M1 - 2017:M12 \\
\hline Food and Beverages (CPIFABSL) & FRED & $\begin{array}{l}\text { Consumer Price Index for All Urban Con- } \\
\text { sumers: Food and Beverages, Index 1982- } \\
\text { 1984=100, Seasonally Adjusted }\end{array}$ & 1983:M1 - 2017:M12 \\
\hline Transportation (CPITRNSL) & FRED & $\begin{array}{l}\text { Consumer Price Index for All Urban Con- } \\
\text { sumers: Transportation, Index 1982-1984=100, } \\
\text { Seasonally Adjusted }\end{array}$ & 1983:M1 - 2017:M12 \\
\hline Apparel (CPIAPPSL) & FRED & $\begin{array}{l}\text { Consumer Price Index for All Urban Con- } \\
\text { sumers: Apparel, Index 1982-1984=100, Sea- } \\
\text { sonally Adjusted }\end{array}$ & 1983:M1 - 2017:M12 \\
\hline Medical Care (CPIMEDSL) & FRED & $\begin{array}{l}\text { Consumer Price Index for All Urban Con- } \\
\text { sumers: Medical Care, Index 1982-1984=100, } \\
\text { Seasonally Adjusted }\end{array}$ & 1983:M1 - 2017:M12 \\
\hline Recreation (CPIRECNS) & FRED & $\begin{array}{l}\text { Consumer Price Index for All Urban Con- } \\
\text { sumers: Recreation, Seasonally Adjusted }\end{array}$ & 1993:M1 - 2017:M12 \\
\hline $\begin{array}{l}\text { Education and Communication } \\
\text { (CPIEDUSL) }\end{array}$ & FRED & $\begin{array}{l}\text { Consumer Price Index for All Urban Con- } \\
\text { sumers: Education and Communication, Index } \\
\text { Dec } 1997=100 \text {, Seasonally Adjusted }\end{array}$ & 1993:M1 - 2017:M12 \\
\hline
\end{tabular}




\begin{tabular}{|c|c|c|c|}
\hline CPI Net of Shelter & Own calculation & $\begin{array}{l}\text { CPI excluding shelter, 1982-1984=100, Season- } \\
\text { ally Adjusted }\end{array}$ & 1983:M1 - 2017:M12 \\
\hline PCE (PCEPI) & FRED & $\begin{array}{l}\text { Personal Consumption Expenditures: Chain- } \\
\text { type Price Index }\end{array}$ & 1983:M1 - 2017:M12 \\
\hline PCE Net of Shelter & Own calculation & $\begin{array}{l}\text { PCE excluding shelter, Chain-type Price Index, } \\
\text { Seasonally Adjusted }\end{array}$ & 1983:M1 - 2017:M12 \\
\hline
\end{tabular}

Table 3: Quarterly Data Description

\begin{tabular}{|c|c|c|c|}
\hline Series & Source & Series Description & Sample \\
\hline Industrial Production & Own calculation & $\begin{array}{l}\text { Quarterly average of the industrial production } \\
\text { monthly data, Seasonally Adjusted }\end{array}$ & 1981:Q1 - 2017:Q4 \\
\hline One-Year Rate & Own calculation & $\begin{array}{l}\text { Quarterly average of the one-year rate monthly } \\
\text { data, Seasonally Adjusted }\end{array}$ & 1981:Q1 - 2017:Q4 \\
\hline Housing Prices (USSTHPI) & FRED & $\begin{array}{l}\text { All-Transactions House Price Index for the } \\
\text { United States, Index 1980:Q1=100, Not Season- } \\
\text { ally Adjusted }\end{array}$ & 1981:Q1 - 2017:Q4 \\
\hline Housing Rents & Own calculation & $\begin{array}{l}\text { Quarterly average of the housing rents monthly } \\
\text { data, Seasonally Adjusted }\end{array}$ & 1981:Q1 - 2017:Q4 \\
\hline $\begin{array}{l}\text { Housing Stock for Renting Vacancy } \\
\text { Rate (RRVRUSQ156N) }\end{array}$ & FRED & $\begin{array}{l}\text { Rental Vacancy Rate for the United States, Per- } \\
\text { cent, Not Seasonally Adjusted }\end{array}$ & 1981:Q1 - 2017:Q4 \\
\hline $\begin{array}{l}\text { Homeownership Rate (RSAHO- } \\
\text { RUSQ156SN) }\end{array}$ & FRED & $\begin{array}{l}\text { Homeownership Rate for the United States, } \\
\text { Percent, Seasonally Adjusted }\end{array}$ & 1981:Q1 - 2017:Q4 \\
\hline
\end{tabular}

\section{FAVAR Model}

The distinguishing feature of the FAVAR relative to a small scale SVAR model is the information structure assumed by the econometrician. ${ }^{17}$ In the FAVAR model, we relax the assumption that both the central bank and the econometrician observe perfectly all of the variables that enter the dynamic system 1. Instead, we assume that we observe perfectly only a subset of $Y_{t}$. All other variables, denoted by $F_{t}$ with dimensions $r<n \times 1$, are assumed to not be observed perfectly by the econometrician but are, nevertheless, strongly correlated with a large number, $N>>n$, of observable economic and financial time series, $X_{t}$. Letting $Y_{t}$ be the set of observable factors and $F_{t}$ the set of unobservable factors, we have that a FAVAR system with $p$ lags is given by

\footnotetext{
${ }^{17}$ For seminal contributions other than Bernanke et al. (2005), see Giannone et al. (2004), Stock and Watson (2005), and Forni et al. (2009). For a formal treatment of the model, see Forni et al. (2009) and Stock and Watson (2016).
} 


$$
\begin{gathered}
{\left[\begin{array}{l}
Y_{t} \\
F_{t}
\end{array}\right]=A(L)\left[\begin{array}{l}
Y_{t-1} \\
F_{t-1}
\end{array}\right]+H \varepsilon_{t}} \\
X_{t}=\Lambda_{F} F_{t}+\Lambda_{Y} Y_{t}+\nu_{t}
\end{gathered}
$$

where $\Lambda_{F}$ is an $N \times r$ matrix of factor loadings related to the unobserved factors, $\Lambda_{Y}$ is an $N \times$ $(n-r)$ matrix of factor loadings related to the observable factors, $A(L)$ is a matrix lag polynomial, and $H$ is an $r \times r$ matrix. The common shocks and the idiosyncratic components are assumed to be uncorrelated at all leads and lags. We estimate 4 and 5 using a two-step principal components procedure and identify the structural shocks through a recursive assumption (as in Bernanke et al. (2005), we assume that factors respond with a lag to changes in the monetary policy indicator). In the FAVAR model that was used in sub-section 4.3, we assume that the federal funds rate is the only factor that is perfectly observable. To determine the number of unobservable factors in the FAVAR model, we used the eigenvalue difference method proposed by Onatski (2010). This method led us to select 3 unobservable factors. Finally, we used the Akaike information criterion approach and selected 12 lags for the FAVAR model. We estimated the model with different combinations of the numbers of factors and lags, and the results remained unchanged. Finally, we used the FRED-MD database (McCracken and $\mathrm{Ng}$ (2016)) that is maintained by the Federal Reserve Bank of St. Louis to estimate the FAVAR model underlying the results in Figure 7. 